\title{
OPEN
}

\section{Author Correction: New microhylid frog genus from Peninsular India with Southeast Asian affinity suggests multiple Cenozoic biotic exchanges between India and Eurasia}

\author{
Sonali Garg \& S. D. Biju
}

Correction to: Scientific Reports https://doi.org/10.1038/s41598-018-38133-x, published online 13 February 2019

In this Article, the legend of Table 1 is incorrect:

"Ages are in Million years; HPD = highest posterior density. Best-fit models are provided in Supplementary Table S4. *Denotes first postulated Miocene exchange; **Denotes second postulated Miocene exchange; $\wedge$ Denotes diversification events associated with periods of isolation."

should read:

"Ages are in Million years; HPD = highest posterior density. Best-fit models are provided in Supplementary Table S4. *Denotes first postulated Eocene exchange; **Denotes second postulated Eocene exchange; $\wedge$ Denotes diversification events associated with periods of isolation."

\begin{abstract}
(c) (i) Open Access This article is licensed under a Creative Commons Attribution 4.0 International License, which permits use, sharing, adaptation, distribution and reproduction in any medium or format, as long as you give appropriate credit to the original author(s) and the source, provide a link to the Creative Commons license, and indicate if changes were made. The images or other third party material in this article are included in the article's Creative Commons license, unless indicated otherwise in a credit line to the material. If material is not included in the article's Creative Commons license and your intended use is not permitted by statutory regulation or exceeds the permitted use, you will need to obtain permission directly from the copyright holder. To view a copy of this license, visit http://creativecommons.org/licenses/by/4.0/.
\end{abstract}

(C) The Author(s) 2019 